Jurnal Media Agribisnis Vol. 3 No. 2 Tahun 2018 Hal. 61 - 72

Media Komunikasi Hasil Penelitian Bidang Ilmu Agribisnis

ISSN print 2548-7027

ISSN online 2541-6898

\title{
DAMPAK UPSUS TERHADAP KESEJAHTERAAN PETANI KEDELAI
}

\author{
Rizki Gemala Busyra \\ Program Studi Agribisnis, Fakultas Pertanian Universitas Batanghari \\ Jl. Slamet Riyadi-Broni, Jambi. 36122. Tel. +6274160103 \\ email: qie_bs@yahoo.com
}

\begin{abstract}
Soybean self-sufficient had became the main target of government since 2015 that concern on two commodities, e.g. rice and maize. Specific effort program called as "Upaya Khusus" (UPSUS) was one of the program to support this selfsufficient of soybean. UPSUS was the main program of the Agriculture Ministry to improve the farmers welfare. The carrying out of this Upsus program was expected to increase soybean production. Increased of soybean production should lead to increased the farmers' income, and would be followed by the increasing of farmers welfare. Rantau Rasau District has participated in this Upsus program to support self-sufficient of soybeans. The purpose of this research was to know the factors influencing soybean production and its income and the Upsus impact of soybean farmer's welfare in Rantau Rasau District. The analytical method was used by constructing 2 structural equations as an econometric model which was analyzed by 2 SLS. The results of this study indicated that factors affecting soybean production on 5 percent significance level were land area, seeds and fertilizer amount. Farmers' income was significantly affected by soybean production, soyben prices, fertilizer prices and labor wages. Specific efforts program (focusing in the increase of land area, seeds and fertilizer amount) that have been held toward to the soybean commodity would give impact on the increase of farmer's income (as one indicator of farmer's walfare).

Keyword: Soybean, UPSUS, Farmers welfare
\end{abstract}

\begin{abstract}
Abstrak
Swasembada kedelai menjadi target utama pemerintah sejak tahun 2015 bersama dua komoditas pangan lain yaitu padi dan jagung. Program UPSUS (Upaya Khusus) merupakan salah satu upaya untuk mendukung swasembada kedelai. Upaya Khusus (UPSUS) merupakan program utama Kementerian Pertanian untuk meningkatkan kesejahteraan petani. Dengan adanya Upsus diharapkan produksi kedelai akan meningkat. Meningkatnya produksi kedelai akan mengakibatkan peningkatan pendapatan petani, sehingga kesejahteraan petani pun akan ikut meningkat. Kecamatan Rantau Rasau telah berpartisipasi dalam program Upsus untuk mendukung swasembada kedelai.Tujuan penelitian adalah untuk mengetahui faktor-faktor yang mempengaruhi produksi kedelai dan pendapatan petani kedelai serta bagaimana dampak Upsus terhadap kesejahteraan petani kedelai di Kecamatan Rantau Rasau. Metode analisis yang digunakan adalah dengan membangun 2 persamaan struktural sebagai model ekonometrika yang dianalisis dengan 2 SLS. Hasil dari penelitian ini menunjukkan bahwa faktorfaktor yang mempengaruhi produksi kedelai pada taraf signifikansi 5 persen adalah luas lahan, jumlah benih dan jumlah pupuk. Pendapatan petani dipengaruhi
\end{abstract}


Jurnal Media Agribisnis Vol. 3 No. 2 Tahun 2018 Hal. 61 - 72

Media Komunikasi Hasil Penelitian Bidang Ilmu Agribisnis

ISSN print 2548-7027

ISSN online 2541-6898

secara signifikan (pada taraf 5 persen) oleh produksi kedelai, harga kedelai, harga pupuk dan upah tenaga kerja. Upaya Khusus yang dilakukan (dalam hal ini adalah peningkatan luas lahan, jumlah benih dan pupuk) kepada komoditas kedelai akan memberikan dampak kepada peningkatan pendapatan petani (sebagai salah satu indikator kesejahteraan petani).

Kata Kunci: Kedelai, UPSUS, Kesejahteraan Petani

\section{PENDAHULUAN}

Swasembada kedelai menjadi target utama pemerintah sejak tahun 2015 bersama dua komoditas pangan lain yaitu padi dan jagung. Untuk mencapai swasembada tersebut diperlukan upaya peningkatan produksi. Upaya peningkatan produksi kedelai terus digulirkan pemerintah pusat. Dana dalam jumlah besar dari Anggaran Pembangunan Belanja Negara (APBN) telah ditetapkan untuk pencapaian target penambahan produksi kedelai bagi setiap daerah. Dengan berbagai bantuan tersebut petani diharapkan bisa meningkatkan produktivitas dan menambah areal tanamnya. Bantuan tersebut kemudian disampaikan kepada para petani dalam bentuk bantuan benih, pupuk, perbaikan irigasi, alat dan mesin pertanian (Busyra, 2016).

Program UPSUS (Upaya Khusus) merupakan salah satu upaya untuk mendukung swasembada kedelai. Kegiatan Upsus yang dilakukan tidak hanya berperan sebagai pengawal dan pengaman penyaluran benih, pupuk, dan alsintan saja, namun selain itu juga mengawal gerakan perbaikan jaringan irigasi, sistem tanam serentak, dan pengendalian Organisme Pengganggu Tanaman (OPT). UPSUS pun juga berperan dalam mempercepat penerapan teknologi peningkatan produksi padi, jagung, dan kedelai melalui Gerakan Penerapan Pengelolaan Tanaman Terpadu (GP-PTT), Perluasan Areal Tanam (PAT), dan optimasi lahan (Busyra, 2016).

Program Upsus dilaksanakan serentak di beberapa provinsi di Indonesia, yaitu Sumatera Utara, Sulawesi Selatan, Jambi, Kalimantan Barat, Kalimantan Selatan, Kalimantan Tengah, Jawa Tengah dan Jawa Timur (Kementerian Pertanian, 2015). Jika dilihat dari produktivitas tanaman kedelai di Kabupaten yang ada di Propinsi Jambi, maka Kabupaten Tanjung Jabung Timur merupakan penyumbang terbesar ke-3 dengan total produksi kedelai sebesar 1.028 ton dengan produktivitas sebesar 1,508 ton/ha. Nilai produktivitas ini lebih tinggi dibandingkan dengan produktivitas Propinsi Jambi yakni sebesar 1,372 ton/ha, hal ini disebabkan Kabupaten Tanjung Jabung Timur merupakan salah satu sentra produksi kedelai di Propinsi Jambi dengan pemanfaatan lahan yang tinggi (Disperta Tanjabtim, 2017). Sentra produksi kedelai di Kabupaten Tanjung Jabung Timur tersebar di beberapa kecamatan, salah satunya yaitu di Kecamatan Rantau Rasau. Kecamatan ini telah berpartisipasi dalam program Upsus untuk mendukung swasembada kedelai.

Upaya Khusus (UPSUS) merupakan program utama Kementerian Pertanian untuk meningkatkan kesejahteraan petani. Dengan adanya Upsus diharapkan produksi kedelai akan meningkat. Meningkatnya produksi kedelai akan mengakibatkan peningkatan pendapatan petani, sehingga kesejahteraan petani pun akan ikut meningkat. Berdasarkan uraian tersebut diatas, maka perlu kiranya 
Jurnal Media Agribisnis Vol. 3 No. 2 Tahun 2018 Hal. 61 - 72

Media Komunikasi Hasil Penelitian Bidang Ilmu Agribisnis

ISSN print 2548-7027

ISSN online 2541-6898

dilakukan penelitian dengan judul "Dampak Upsus Terhadap Kesejahteraan Petani Kedelai".

\section{METODOLOGI PENELITIAN}

Penelitian dan pengambilan data dilapangan dilaksanakan pada bulan Januari sampai Agustus 2018, di Kecamatan Rantau Rasau Kabupaten Tanjung Jabung Timur Provinsi Jambi. Jenis data yang digunakan dalam penelitian ini adalah data primer dan data sekunder. Data Primer berupa data yang diambil langsung dari petani yang terpilih sebagai sampel, pengambilan data dilakukan dengan wawancara langsung pada responden dengan menggunakan daftar pertanyaan yang terpola dan terstruktur sesuai dengan kebutuhan. Data Sekunder merupakan data tambahan yang diperoleh dari Dinas Pertanian Provinsi Jambi, Dinas Pertanian Kabupaten Tanjung Timur, Badan Pusat Statistik (BPS) Jambi dan Kabupaten Tanjung Timur, Badan Pengkajian Teknologi Pertanian (BPTP) Jambi, Dinas Perindustrian dan Perdagangan Provinsi Jambi, dan dari berbagai informasi-informasi lain seperti jurnal-jurnal pertanian, ekonomi dan hasil penelitian terdahulu serta pada beberapa situs di internet. Penelitian dilakukan dengan metode survey. Pengolahan data dilakukan dengan program komputer yaitu: SAS for Windows 9.0.

Model merupakan suatu penjelas dari fenomena aktual sebagai suatu sistem atau proses (Koutsoyiannis, 1977). Model ekonometrika adalah suatu pola khusus dari model aljabar, yakni suatu unsur yang bersifat stochastic yang mencakup satu atau lebih peubah pengganggu (Intriligator, 1978).

Model ekonometrika merupakan gambaran dari hubungan masing-masing variabel penjelas (explanatory variables) terhadap peubah endogen (dependent variables) khususnya yang menyangkut tanda dan besaran (magnitude and sign) dari penduga parameter sesuai dengan harapan teoritis secara apriori. Model yang baik haruslah memenuhi kriteria teori ekonomi (theoritically meaningful), kriteria statistika yang dilihat dari suatu derajat ketepatan ( goodness of fit) yang dikenal dengan koefisien determinasi $\left(\mathrm{R}^{2}\right)$ serta nyata secara statistik (statistically significant) sedangkan kriteria ekonometrika menetapkan apakah suatu taksiran memiliki sifat-sifat yang dibutuhkan seperti unbiasedness, consistency, sufficiency, efficiency. Statistik $\mathrm{D}_{\mathrm{w}}$ adalah salah satu kriteria ekonometrika yang digunakan untuk menguji taksiran, yaitu menguji validitas dari asumsi autocorrelation (Koutsoyiannis, 1977).

Spesifikasi model yang dirumuskan dalam penelitian ini adalah sangat terkait dengan tujuan penelitian yaitu bagaimana dampak upsus terhadap kesejahteraan petani kedelai. Persamaan yang disusun adalah persamaan struktural produksi dan pendapatan. Model yang dibangun adalah model ekonometrika persamaan simultan.

\section{Produksi Kedelai}

Faktor-faktor yang diduga mempengaruhi produksi kedelai di Kecamatan Rantau Rasau adalah luas lahan, jumlah benih, jumlah pupuk, jumlah pestisida dan jumlah tenaga kerja yang digunakan. Persamaan produksi kedelai adalah: $\mathrm{PK}=\mathrm{a}_{0}+\mathrm{a}_{1} \mathrm{LL}+\mathrm{a}_{2} \mathrm{BNH}+\mathrm{a}_{3} \mathrm{PU}+\mathrm{a}_{4} \mathrm{PEST}+\mathrm{a}_{5} \mathrm{JTK}+\mathrm{U}_{1}$ 
Jurnal Media Agribisnis Vol. 3 No. 2 Tahun 2018 Hal. 61 - 72

Media Komunikasi Hasil Penelitian Bidang Ilmu Agribisnis

ISSN print 2548-7027

ISSN online 2541-6898

dimana:

PK $=$ Produksi Kedelai $(\mathrm{Kg})$

LL $\quad=$ Luas Lahan Kedelai $(\mathrm{Ha})$

$\mathrm{BNH}=$ Jumlah Benih Yang Digunakan $(\mathrm{Kg})$

PU $\quad=$ Jumlah Pupuk Yang Digunakan $(\mathrm{Kg})$

PEST $\quad=$ Jumlah Pestisida Yang Digunakan (Liter)

JTK = Jumlah Tenaga Kerja (Orang)

Tanda parameter yang diharapkan adalah:

$a_{1}, a_{2}, a_{3}, a_{4}, a_{5}>0$

\section{Pendapatan Petani Kedelai}

Pendapatan petani kedelai di Kecamatan Rantau Rasau diduga dipengaruhi oleh produksi kedelai, harga kedelai, harga pupuk, harga pestisida dan upah tenaga kerja.

$\mathrm{I}=\mathrm{b}_{0}+\mathrm{b}_{1} \mathrm{PK}+\mathrm{b}_{2} \mathrm{HK}+\mathrm{b}_{3} \mathrm{HPU}+\mathrm{b}_{4} \mathrm{HPEST}+\mathrm{b}_{5} \mathrm{UTK}+\mathrm{U}_{2}$

dimana:

$\mathrm{I} \quad=$ Pendapatan Petani $(\mathrm{Rp} / \mathrm{Ha})$

PK $\quad=$ Produksi Kedelai $(\mathrm{Kg})$

$\mathrm{HK} \quad=$ Harga Kedelai $(\mathrm{Rp} / \mathrm{Kg})$

HPU $\quad=$ Harga Pupuk $(\mathrm{Rp} / \mathrm{Kg})$

HPEST = Harga Pestisida $(\mathrm{Rp} /$ Liter $)$

UTK $\quad=$ Upah Tenaga Kerja $(\mathrm{Rp} / \mathrm{Ha})$

Tanda parameter dugaan yang diharapkan:

$$
\mathrm{b}_{1}, \mathrm{~b}_{2}>0 ; \quad \mathrm{b}_{3}, \mathrm{~b}_{4}, \mathrm{~b}_{5}<0 \text {; }
$$

Identifikasi model ditentukan atas dasar "order condition" sebagai syarat keharusan dan "rank condition" sebagai syarat kecukupan. Rumusan identifikasi model persamaan struktural berdasarkan order condition adalah (Koutsoyiannis, 1977):

$$
(\mathrm{K}-\mathrm{M})>(\mathrm{G}-1)
$$

dimana:

$\mathrm{K} \quad=$ Total variabel dalam model, yaitu endogenous variables dan predetermined variables.

$\mathrm{M} \quad=$ Jumlah variabel endogen dan eksogen yang termasuk dalam satu persamaan tertentu dalam model, dan

$\mathrm{G}=$ Total persamaan dalam model, yaitu jumlah variabel endogen dalam model.

Jika dalam suatu persamaan model menunjukkan kondisi sebagai berikut:

$(\mathrm{K}-\mathrm{M})>(\mathrm{G}-1)=$ maka persamaan dinyatakan teridentifikasi secara berlebih (overidentified)

$(\mathrm{K}-\mathrm{M})=(\mathrm{G}-1)=$ maka persamaan tersebut dinyatakan teridentifikasi secara tepat (exactly identified), dan

$(\mathrm{K}-\mathrm{M})<(\mathrm{G}-1)=$ maka persamaan tersebut dinyatakan tidak teridentifikasi (unidentified).

Hasil identifikasi untuk setiap persamaan struktural haruslah exactly identified atau overidentified untuk dapat menduga parameter-parameternya. Pada 
Jurnal Media Agribisnis Vol. 3 No. 2 Tahun 2018 Hal. 61 - 72

Media Komunikasi Hasil Penelitian Bidang Ilmu Agribisnis

ISSN print 2548-7027

ISSN online 2541-6898

penelitian ini jumlah $\mathrm{K}=11, \mathrm{M}=5$ dan $\mathrm{G}=1$, sehingga persamaan dinyatakan teridentifikasi secara berlebih (overidentified).

Dari hasil identifikasi model diketahui bahwa semua persamaan dalam model adalah overidentified. Persamaan yang demikian dapat diduga dengan menggunakan 2SLS (Two Stage Least Squares), dengan beberapa pertimbangan, yaitu penerapan 2 SLS menghasilkan taksiran yang konsisten, lebih sederhana dan lebih mudah (Gujarati, 2003).

Untuk mengetahui dan menguji apakah variabel penjelas secara bersamasama berpengaruh nyata atau tidak terhadap variabel endogen, maka pada setiap persamaan digunakan uji statistik $\mathrm{F}$, dan untuk menguji apakah masing-masing variabel penjelas berpengaruh nyata atau tidak terhadap variabel endogen, maka pada setiap persamaan digunakan uji statistik t.

Untuk mengetahui apakah model cukup valid untuk membuat suatu simulasi kebijakan pertanian dan faktor eksternal dan peramalan, maka perlu dilakukan suatu validasi model, dengan tujuan untuk menganalisis sejauhmana model tersebut dapat mewakili dunia nyata.

Dalam penelitian ini, kriteria statistik untuk validasi nilai pendugaan model ekonometrika yang digunakan adalah Root Means Square Error (RMSE), Root Means Percent Square Error (RMSPE) dan Theil's Inequality Coefficient (U) (Pindyck and Rubinfield, 1991). Kriteria - kriteria dirumuskan sebagai berikut:

$$
\begin{aligned}
& R M S E=\sqrt{\frac{1}{n} \sum_{t=1}^{n}\left(Y_{t}^{S}-Y_{t}^{a}\right)^{2}} \\
& R M S P E=\sqrt{\frac{1}{n} \sum_{t=1}^{n}\left(\frac{Y_{t}^{s}-Y_{t}^{a}}{Y_{t}^{a}}\right)^{2}} \\
& U=\frac{\sqrt{\frac{1}{n} \sum_{t=1}^{n}\left(Y_{t}^{s}-Y_{t}^{a}\right)^{2}}}{\sqrt{\frac{1}{n} \sum_{t=1}^{n}\left(Y_{t}^{s}\right)^{2}}+\sqrt{\frac{1}{n} \sum_{t=1}^{n}\left(Y_{t}^{a}\right)^{0.5}}}
\end{aligned}
$$

dimana:

$Y_{t}^{S}=$ nilai hasil simulasi dasar dari variabel observasi

$Y_{t}^{a}=$ nilai aktual variabel observasi

$n=$ jumlah periode observasi

Statistik RMSPE digunakan untuk mengukur seberapa jauh nilai-nilai peubah endogen hasil pendugaan menyimpang dari alur nilai-nilai aktualnya dalam ukuran relatif (persen), atau seberapa dekat nilai dugaan itu mengikuti perkembangan nilai aktualnya.

Sedangkan nilai statistik $U$ bermanfaat untuk mengetahui kemampuan model untuk analisis simulasi peramalan. Nilai koefisien Theil (U) berkisar antara 1 dan 0 . Jika $U=0$ maka pendugaan model sempurna, jika $U=1$ maka pendugaan model naif. 
Jurnal Media Agribisnis Vol. 3 No. 2 Tahun 2018 Hal. 61 - 72

Media Komunikasi Hasil Penelitian Bidang Ilmu Agribisnis

ISSN print 2548-7027

ISSN online 2541-6898

Untuk melihat keeratan arah (slope) antara aktual dengan hasil yang disimulasi dilihat dari nilai koefisien determinasinya $\left(\mathrm{R}^{2}\right)$. Pada dasarnya makin kecil nilai RMSPE dan U-Theil's dan makin besar nilai $\mathrm{R}^{2}$, maka pendugaan model semakin baik.

Setelah divalidasi, prosedur berikutnya adalah simulasi model. Analisis simulasi digunakan untuk menjelaskan dampak upsus terhadap kesejahteraan petani. Analisis simulasi diterapkan pada periode Januari 2015 - Januari 2018, karena pogram upsus baru dilaksanakan sejak tahun 2015 dan data lebih lengkap dan terjamin.

Analisis ini mencakup periode yang sudah lampau, sehingga simulasi ini dinamakan simulasi historis. Dengan demikian beberapa skenario simulasi alternatif dampak program upsus pajale terhadap komoditas kedelai, yaitu:

1. Peningkatan luas lahan kedelai sebesar 5 persen.

Simulasi ini dilakukan berdasarkan data perkembangan areal kedelai di

Kecamatan Rantau Rasau Kabupaten Tanjung Timur, dimana peningkatan lahan tertinggi adalah sebesar 5 persen dalam 2 tahun terakhir.

2. Peningkatan jumlah subsidi benih dan pupuk sebesar 6 persen secara serentak.

Simulasi ini dilakukan berdasarkan kegiatan upsus pajale di Kecamatan Rantau

Rasau Kabupaten Tanjung Jabung Timur.

3. Peningkatan produksi kedelai sebesar 95 persen

4. Peningkatan harga kedelai sebesar 7 persen.

\section{Gambaran Umum Hasil Estimasi Model}

\section{HASIL DAN PEMBAHASAN}

Model kesejahteraan petani kedelai di Kecamatan Rantau Rasau Kabupaten Tanjung Jabung Timur dalam penelitian ini merupakan model simultan dinamis yang dibangun dari 2 persamaan. Model yang dibangun menggambarkan adanya keterkaitan antara kebijakan upaya khusus pada komoditas kedelai dengan kesejahteraan petani (dilihat dari segi pendapatan). Data yang digunakan adalah data permusim tanam komoditas kedelai pada Kecamatan Rantau Rasau Kabupaten Tanjung Jabung Timur.

Secara umum hasil estimasi model dapat dijelaskan bahwa persamaanpersamaan dalam model pada umumnya telah sesuai dengan pertimbanganpertimbangan ekonomi dan statistik sehingga model dimaksud mampu menggambarkan fenomena-fenomena yang berkaitan dengan komoditas kedelai di dunia nyata. Seluruh persamaan perilaku memiliki koefisien determinasi $\left(\mathrm{R}^{2}\right)$ di atas 0.92 (mencapai 0.97). Kondisi ini menunjukkan bahwa secara umum kemampuan peubah-peubah penjelas yang ada pada persamaan perilaku mampu menjelaskan dengan baik peubah endogennya.

Nilai statistik F dalam model umumnya nyata secara statistik, yaitu berkisar antara 735.79 sampai 2183.40, yang berarti variasi peubah-peubah penjelas dalam setiap persamaan perilaku secara bersama-sama mampu menjelaskan dengan baik variasi peubah endogennya. Sedangkan untuk variabel penjelas secara individual terdapat beberapa variabel penjelas yang tidak berepengaruh nyata terhadap peubah endogen. Hasil penelitian menunjukkan adanya nilai $t$ statistik yang beragam tingkat signifikansinya. 
Jurnal Media Agribisnis Vol. 3 No. 2 Tahun 2018 Hal. 61 - 72

Media Komunikasi Hasil Penelitian Bidang Ilmu Agribisnis

ISSN print 2548-7027

ISSN online 2541-6898

Nilai statistik Durbin Watson persamaan struktural dalam model berkisar antara 1.989218 sampai 2.117116 . Hal ini mengindikasikan tidak ada persamaan yang mengandung masalah autokorelasi.

Untuk melihat respon peubah endogen terhadap peubah penjelas dari masingmasing persamaan digunakan koefisien elastisitas. Peubah endogen dikatakan responsif (elastis) terhadap perubahan peubah penjelas apabila nilai elastisitasnya lebih besar dari satu $(>1)$ dan tidak responsif (in elastis) apabila nilai elastisitasnya lebih kecil dari satu $(\leq 1)$.

\section{Pembahasan Model Estimasi}

Model Dampak Upaya Khusus (UPSUS) Terhadap Kesejahteraan Petani Kedelai terdiri dari 2 persamaan struktural sebagai berikut:

\section{A. Produksi Kedelai}

Pada Tabel 1 menunjukkan bahwa peubah penjelas pada persamaan produksi kedelai mampu menjelaskan secara baik $(92.543 \%)$ keragaman perkembangan produksi kedelai. Produksi kedelai berhubungan positif dengan luas lahan kedelai, jumlah benih, jumlahpupuk, jumlah pestisida dan jumlah tenaga kerja yang digunakan. Semua tanda ekonomi pada persamaan ini telah sesuai dengan harapan. Perilaku produksi kedelai dipengaruhi secara nyata pada taraf 5 persen oleh luas lahan kedelai, jumlah benih dan jumlah pupuk.

Perubahan luas lahan kedelai sebesar satu hektar akan mengakibatkan perubahan produksi kedelai sebesar $2.554869 \mathrm{~kg}$, hal ini sejalan dengan penelitian Busyra (2016), disebabkan dengan adanya peningkatan luas lahan maka petani akan menanam kedelai dengan jumlah yang lebih banyak sehingga produksi kedelai meningkat.

Tabel 1. Hasil Estimasi Persamaan Produksi Kedelai

\begin{tabular}{|c|c|c|c|c|}
\hline Variabel & $\begin{array}{c}\text { Parameter } \\
\text { Estimasi }\end{array}$ & Prob $>|t|$ & Label & \\
\hline Intercept & 0.00001 & 0.0001 & Intercept & \\
\hline LL & 2.554869 & 0.0028 & Luas lahan (Ha) & \\
\hline $\mathrm{BNH}$ & 1.32766 & 0.0045 & Jumlah benih $(\mathrm{Kg})$ & \\
\hline PU & 0.12824 & 0.0318 & Jumlah pupuk (Kg) & \\
\hline PEST & 0.00172 & 0.1512 & Jumlah Pestisida (Liter) & \\
\hline JTK & 0.998060 & 0.1024 & Jumlah Tenaga Kerja (Orang) & \\
\hline R-Square & 0.92543 & & Dw & 1.989218 \\
\hline F-hit & 2183.40 & & & \\
\hline
\end{tabular}

Sumber: Data Olahan Primer, 2018

Besarnya perubahan Produksi Kedelai (PK) sebagai akibat perubahan jumlah benih yang digunakan sebesar $1 \mathrm{~kg}$ adalah sebesar $1.32766 \mathrm{~kg}$ (sejalan dengan penelitian Busyra, 2014). Hal ini dikarenakan terjadinya penambahan jumlah benih yang digunakan maka jumlah produksi kedelai pun akan meningkat. 
Jurnal Media Agribisnis Vol. 3 No. 2 Tahun 2018 Hal. 61 - 72

Media Komunikasi Hasil Penelitian Bidang Ilmu Agribisnis

ISSN print 2548-7027

ISSN online 2541-6898

Perubahan jumlah pupuk sebesar $1 \mathrm{~kg}$ akan mengakibatkan perubahan produksi kedelai sebesar $0.12824 \mathrm{Kg}$ (kurang dari 1 persen), hal ini dikarenakan petani masih belum menggunakan pupuk sesuai dengan dosisnya.

\section{B. Pendapatan Petani}

Hasil pada Tabel 2 menunjukkan bahwa peubah penjelas pada persamaan pendapatan petani kedelai mampu menjelaskan secara baik yaitu sebesar 97.812 $\%$. Pendapatan petani berhubungan positif dengan produksi kedelai dan harga kedelai. Serta berhubungan negatif dengan harga pupuk, harga pestisida dan upah tenaga kerja. Persamaan pendapatan petani dipengaruhi secara nyata pada taraf nyata 5 persen oleh produksi kedelai, harga kedelai, harga pupuk dan upah tenaga kerja.

Perubahan produksi kedelai sebesar $1 \mathrm{~kg}$ akan mengakibatkan perubahan pendapatan petani sebesar Rp. 2.906214/Ha. Hal ini dikarenakan penambahan produksi kedelai akan meningkatkan jumlah penjualan kedelai sehingga menyebabkan pendapatan petanipun meningkat.

Perubahan harga kedelai sebesar Rp. 1,-/kilogram akan mengakibatkan perubahan pendapatan petani sebesar Rp. 1.820001/Kg. Hal ini dikarenakan semakin tinggi harga kedelai maka petani akan mendapatkan keuntungan lebih banyak sehingga mengakibatkan pendapatan petani meningkat.

Perubahan harga pupuk sebesar Rp. 1,-/kg akan mengakibatkan perubahan pendapatan petani sebesar Rp.1.435800/Kg. Karena pupuk merupakan salah satu faktor produksi dalam usahatani kedelai, Semakin besar biaya yang dikeluarkan untuk membeli pupuk akan mengakibatkan semakin kecilnya pendapatan yang diterima petani.

Perubahan upah tenaga kerja sebesar Rp. 1,-/orang akan mengakibatkan perubahan pendapatan petani sebesar Rp. 2.657823/orang. Penyebabnya adalah semakin mahal upah tenaga kerja maka semakin besar biaya yang dikeluarkan petani, sehingga pendapatan petani akan menurun.

Tabel 2. Hasil Estimasi Persamaan Pendapatan Petani

\begin{tabular}{|c|c|c|c|}
\hline Variabel & Parameter Estimasi & Prob $>|t|$ & Label \\
\hline Intercept & -0.04947 & 0.4501 & Intercept \\
\hline PK & 2.906214 & $<.0001$ & Produksi Kedelai (Kg) \\
\hline HK & 1.820001 & $<.0001$ & Harga Kedelai (Rp/Kg) \\
\hline HPU & -1.435800 & $<.0001$ & Harga Pupuk (Rp/Kg) \\
\hline HPEST & -0.000544 & 0.1021 & Harga Pestisida (Rp/Liter) \\
\hline UTK & -2.657823 & $<.0001$ & Upah Tenaga Kerja (Rp/Orang) \\
\hline R-Square & 0.97812 & & $\begin{array}{ll}\text { Dw } & 2.117116\end{array}$ \\
\hline F-hit & 735.79 & & \\
\hline
\end{tabular}

Sumber: Data Olahan Primer, 2018 
Jurnal Media Agribisnis Vol. 3 No. 2 Tahun 2018 Hal. 61 - 72

Media Komunikasi Hasil Penelitian Bidang Ilmu Agribisnis

ISSN print 2548-7027

ISSN online 2541-6898

\section{Evaluasi Daya Prediksi Model}

Validasi model dilakukan secara historis, ada 2 peubah endogen yang divalidasi, hasil validasi model menunjukkan bahwa sebagian besar variabel endogen memiliki nilai rata-rata RMSPE sebesar 3.98 persen dan U-Theil sebesar 0.15. Dari kondisi tersebut dapat disimpulkan bahwa sebagian besar persamaan di dalam model memiliki daya prediksi yang baik, dan cukup valid untuk melakukan simulasi.

\section{Dampak Upaya Khusus (UPSUS) Terhadap Kesejahteraan Petani Kedelai}

Evaluasi dampak penerapan alternatif kebijakan upsus terhadap kesejahteraan petani kedelai dibatasi kepada perubahan variabel yang terkait dengan kebijakan upsus, yaitu peningkatan luas lahan kedelai, peningkatan jumlah subsidi benih dan pupuk, peningkatan produksi kedelai dan peningkatan harga kedelai. Evaluasi dilakukan terhadap 4 skenario simulasi historis. Berikut ini dikemukakan hasil simulasi pada masing-masing skenario.

\section{A. Peningkatan Luas Lahan Kedelai}

Dari Tabel 3 dapat dijelaskan bahwa peningkatan luas lahan kedelai sebesar 5 persen menyebabkan peningkatan produksi kedelai sebesar 8.7682 persen. Hal ini sesuai dengan hasil estimasi dimana peningkatan luas lahan kedelai berpengaruh nyata dalam meningkatkan produksi kedelai. Selain itu peningkatan produksi kedelai akan diikuti oleh peningkatan pendapatan petani kedelai sebesar 38.2649 persen. Hal ini sejalan dengan hasil estimasi dimana produksi kedelai berpengaruh nyata terhadap pendapatan petani. Peningkatan pendapatan petani akan berpengaruh terhadap peningkatan kesejahteraan petani.

Tabel 3. Dampak Peningkatan Luas Lahan Kedelai sebesar 5 persen terhadap Kesejahteraan Petani Kedelai

\begin{tabular}{clrrr}
\hline No & \multicolumn{1}{c}{ Variabel Endogen } & Nilai Dasar & $\begin{array}{c}\text { Nilai } \\
\text { Simulasi }\end{array}$ & $\begin{array}{r}\text { Perubahan } \\
(\%)\end{array}$ \\
\hline 1 & Produksi Kedelai & 3256.1 & 3541.6 & 8.7682 \\
2 & Pendapatan Petani & 4.265 & 5.897 & 38.2649 \\
\hline
\end{tabular}

Sumber: Data Olahan Primer, 2018

\section{B. Peningkatan Jumlah Bantuan Benih Dan Pupuk}

Tabel 4 memperlihatkan bahwa peningkatan pemberian subsidi benih dan pupuk masing-masingnya sebesar 6 persen akan menyebabkan produksi kedelai meningkat sebesar 46.9642 persen. Hal ini sesuai dengan hasil estimasi dimana peningkatan subsidi benih dan pupuk berpengaruh nyata dalam meningkatkan produksi kedelai. Selain itu peningkatan produksi kedelai akan mengakibatkan peningkatan pendapatan petani sebesar 53.9742 persen. Peningkatan pendapatan petani akan berpengaruh terhadap peningkatan kesejahteraan petani. 
Jurnal Media Agribisnis Vol. 3 No. 2 Tahun 2018 Hal. 61 - 72

Media Komunikasi Hasil Penelitian Bidang Ilmu Agribisnis

ISSN print 2548-7027

ISSN online 2541-6898

Tabel 4. Dampak Peningkatan Subsidi Benih dan Pupuk sebesar 6 persen terhadap Kesejahteraan Petani Kedelai

\begin{tabular}{clrrr}
\hline No & Variabel Endogen & Nilai Dasar & Nilai Simulasi & $\begin{array}{c}\text { Perubahan } \\
(\%)\end{array}$ \\
\hline 1 & Produksi Kedelai & 3256.1 & 4785.3 & 46.9642 \\
2 & Pendapatan Petani & 4.265 & 6.567 & 53.9742 \\
\hline
\end{tabular}

Sumber: Data Olahan Primer, 2018

\section{Peningkatan Produksi Kedelai}

Pada Tabel 5 dapat dilihat bahwa peningkatan produksi kedelai sebesar 95 persen akan meningkatkan pendapatan petani sebesar 80 persen. Hal ini sesuai dengan hasil estimasi dimana peningkatan produksi kedelai berpengaruh nyata dalam meningkatkan peningkatan pendapatan petani.

Tabel 5. Dampak Peningkatan Produksi Kedelai sebesar 95 persen terhadap Kesejahteraan Petani Kedelai

\begin{tabular}{clrrr}
\hline No & Variabel Endogen & Nilai Dasar & Nilai Simulasi & $\begin{array}{c}\text { Perubahan } \\
(\%)\end{array}$ \\
\hline 1 & Produksi Kedelai & 3256.1 & 6349.40 & 95.0000 \\
2 & Pendapatan Petani & 4.265 & 7.677 & 80.0000 \\
\hline
\end{tabular}

Sumber: Data Olahan Primer, 2018

\section{Peningkatan Harga Kedelai}

Tabel 6 menunjukkan bahwa peningkatan harga kedelai sebesar 7 persen akan meningkatkan pendapatan petani sebesar 37.7726 persen. Hal ini sesuai dengan hasil estimasi dimana peningkatan harga kedelai berpengaruh nyata dalam meningkatkan pendapatan petani.

Tabel 6. Dampak Peningkatan Subsidi Harga Kedelai sebesar 7 persen terhadap Kesejahteraan Petani Kedelai

\begin{tabular}{ccrrr}
\hline No & Variabel Endogen & Nilai Dasar & Nilai Simulasi & $\begin{array}{c}\text { Perubahan } \\
(\%)\end{array}$ \\
\hline 1 & Produksi Kedelai & 3256.1 & 3889.3 & 19.4466 \\
2 & Pendapatan Petani & 4.265 & 5.876 & 37.7726 \\
\hline
\end{tabular}

Sumber: Data Olahan Primer, 2018

Selain itu peningkatan harga kedelai dapat memberikan stimulus bagi petani dalam meningkatkan produksi kedelai, sehingga pada Tabel 6 dapat dilihat peningkatan produksi kedelai akibat peningkatan harga kedelai sebesar 19.4466 persen. 
Jurnal Media Agribisnis Vol. 3 No. 2 Tahun 2018 Hal. 61 - 72

Media Komunikasi Hasil Penelitian Bidang Ilmu Agribisnis

ISSN print 2548-7027

ISSN online 2541-6898

\section{KESIMPULAN}

Berdasarkan hasil penelitian yang telah dikemukakan di atas, maka dapat ditarik beberapa kesimpulan sebagai berikut:

1. Faktor-faktor yang mempengaruhi produksi kedelai adalah luas lahan, jumlah benih dan jumlah pupuk. Pendapatan petani dipengaruhi secara signifikan oleh produksi kedelai, harga kedelai, harga pupuk dan upah tenaga kerja.

2. Upaya Khusus yang dilakukan (dalam hal ini adalah peningkatan luas lahan, jumlah benih dan pupuk) kepada komoditas kedelai akan berdampak kepada peningkatan pendapatan petani (sebagai salah satu indikator kesejahteraan petani).

\section{DAFTAR PUSTAKA}

A.T. Mosher. 1987. Menggerakkan Dan Membangun Pertanian. Yasaguna. Jakarta.

Badan Pusat Statistik Indonesia. 2000. Indonesia Dalam Angka. Badan Pusat Statistik. Jakarta.

Badan Pusat Statistik Provinsi Jambi. 2016. Jambi Dalam Angka. Badan Pusat Statistik Provinsi Jambi. Jambi.

Busyra, R.G. 2014. Dampak Perluasan Areal Pada Komoditas Karet Terhadap Perekonomian Provinsi Jambi. Jurnal Ekonomi Pertanian, Sumberdaya dan Lingkungan, IPB Bogor, ISSN: 2088-9364 Vol.1 No. 2 Oktober 2014. . 2016. Dampak Program Upaya Khusus (UPSUS) Padi Jagung Kedelai (Pajale) Pada Komoditas Padi Terhadap Perekonomian Kabupaten Tanjung Jabung Timur. Jurnal Media Agribisnis (MeA) Vol.1 No.1 : 1227.

Dinas Pertanian Kabupaten Tanjung Jabung Timur. 2017. Dinas Pertanian Tanaman Pangan Dalam Angka. Dinas Pertanian Kabupaten Tanjung Jabung Timur. Kabupaten Tanjung Jabung Timur.

Ghozali, I. 2008. Aplikasi Analisis Multivariate Dengan Program SPSS. Undip Press. Semarang.

Gujarati, D. 2003. Ekonometrika Dasar. Terjemahan. Erlangga. Jakarta.

Hutagalung, M. 2007. Dampak Peningkatan Harga Beras Terhadap Tingkat Kesejahteraan Petani Pada Beberapa Strata Luas Lahan. Skripsi Departemen Sosial Ekonomi Pertanian Fakultas Pertanian Universitas Sumatera Utara. Medan.

Intriligator, M.D. 1978. Econometric Model. Techniques. and Applications. Prentice Hall Inc. New Jersey.

Kementerian Pertanian.2015. Peraturan Menteri Pertanian No. 03 Tahun 2015 tentang Pedoman Upaya Khusus (UPSUS) Peningkatan Produksi Padi, Jagung, dan Kedelai Melalui Program Perbaikan Jaringan Irigasi da Sarana Pendukungnya Tahun Anggaran 2015. Jakarta.

Koutsoyiannis. 1977. Theory of Econometrics: An Introductory Exposition of Econometric Methods. Second Edition. Macmillan Publishers Ltd. London.

Lumbanraja, M. 2013. Pengaruh Kredit Pertanian Terhadap Kesejahteraan Petani Kelapa Sawit Di Kabupaten Labuhan Ratu Utara. Jurnal Ekonomi dan 
Jurnal Media Agribisnis Vol. 3 No. 2 Tahun 2018 Hal. 61 - 72

Media Komunikasi Hasil Penelitian Bidang Ilmu Agribisnis

ISSN print 2548-7027

ISSN online 2541-6898

Keuangan Vol.1 No.10 Universitas Sumatera. Medan.

Pindyck, R.S. and D.L. Rubinfeld. 1991. Econometrics Models and Economic Forecast. Third Edition. McGraw-Hill Inc. New York.

Poerwadarminta, W.J.S. 2003. Kamus Umum Bahasa Indonesia. Balai Pustaka. Jakarta

Rizieq, R. 2010. Dampak Subsidi Pupuk Terhadap Kesejahteraan Petani. Jurnal Soca Vol. 10 (2) : 121 - 127. ISSN: 1411-7177.

Santoso,S. 2000. Buku Latihan SPSS Statistik Parametrik. Elex Media Komputindo. Jakarta.

Undang-Undang Republik Indonesia Nomor 11 Tahun 2019 Tentang Kesejahteraan Sosial.

Utomo, Y.P. 2007. Eksplorasi data dan analisis Regresi dengan SPSS. Muhammadiyah University Press. Surakarta. 